\title{
Burden in family caregivers of the elderly: prevalence and association with characteristics of the elderly and the caregivers*
}

\author{
SOBRECARGA DE CUIDADORES FAMILIARES DE IDOSOS: PREVALÊNCIA E ASSOCIAÇÃO \\ COM CARACTERÍSTICAS DO IDOSO E DO CUIDADOR
}

\author{
SOBRECARGA DE LOS CUIDADORES FAMILIARES DEL ADULTO MAYOR: PREVALENCIA \\ Y ASOCIACIÓN CON LAS CARACTERÍSTICAS DEL ADULTO MAYOR Y DEL CUIDADOR
}

\section{Lara de Sá Neves Loureiro', Maria das Graças Melo Fernandes², Sueli Marques³, Maria Miriam Lima da Nóbrega ${ }^{4}$, Rosalina A. Partezani Rodrigues ${ }^{5}$}

\begin{abstract}
A cross-sectional, epidemiological study aimed to estimate the prevalence of burden among family caregivers of impaired elderly residents in the city of João Pessoa, and to identify associations between the mean burden and social and demographic characteristics of the elderly and the caregivers. A total number of 240 elderly residents in a previously drawn census tract participated in this research. The sample was composed of 52 elderly and their caregivers. For data collection, a questionnaire was applied with questions on social and demographic characteristics of elderly and caregivers, and the Burden Interview Scale was used. Results showed a high prevalence of burden among caregivers (84.6\%), in which a statistically significant association was found with the following characteristics: retired elderly, elderly as head of family, spousal caregivers, and caregivers with less education. The findings of this study may contribute to the development of activities focused on formal and emotional support for the caregivers.
\end{abstract}

\section{RESUMO}

Pesquisa de natureza epidemiológica, descritiva e transversal, que teve como objetivos estimar a prevalência de sobrecarga entre os cuidadores familiares de idosos dependentes, residentes no município de João Pessoa, e identificar possíveis associações entre a sobrecarga e as características sociodemográficas de idosos e cuidadores. A população foi constituída por 240 idosos residentes nos setores censitários sorteados no referido Município. Compuseram a amostra 52 idosos e seus cuidadores familiares. Para a coleta dos dados, aplicou-se um questionário semiestruturado com questões referentes às características sociodemográficas dos idosos e dos cuidadores e a escala Burden Interview. Os resultados demonstraram alta prevalência de sobrecarga entre os cuidadores $(84,6 \%)$, a qual apresentou associação estatisticamente significativa com as seguintes características: idosos aposentados e responsáveis pelo domicílio, cuidadores cônjuges dos idosos e que apresentaram menor grau de escolaridade. Os achados trazem contribuições para a elaboração de ações direcionadas ao estabelecimento de suportes formais e emocionais para os cuidadores.

\author{
DESCRITORES \\ Idoso \\ Cuidadores \\ Familia \\ Enfermagem geriátrica
}

\begin{abstract}
RESUMEN
Investigación epidemiológica, descriptiva y transversal que tuvo como objetivos: estimar la prevalencia de la sobrecarga entre los cuidadores familiares del adulto mayor dependientes, residentes en el municipio de João Pessoa e identificar posibles asociaciones entre la sobrecarga y las características socio-demográficas del adulto mayor y de los cuidadores. La población fue constituída por 240 adultos mayores residentes en las zonas censales sorteadas en dicho municipio. Se obtuvo una muestra de 52 adultos mayores y sus cuidadores familiares. Para la recolección de los datos, se aplicó un cuestionario semiestructurado con cuestiones referentes a las características socio-demográficas de los adultos mayores y de los cuidadores y la escala Burden Interview. Los resultados demostraron alta prevalencia de sobrecarga entre los cuidadores $(84,6 \%)$, la cual presentó una asociación estadísticamente significativa con las siguientes características: adultos mayores jubilados y responsables por el domicilio, cuidadores cónyuges de los adultos mayores y con menor grado de escolaridad. Los hallazgos traen contribuciones para la elaboración de acciones dirigidas a establecer soportes formales y emocionales para los cuidadores.
\end{abstract}

\section{DESCRIPTORES \\ Anciano \\ Cuidadores \\ Familia \\ Enfermería geriátrica}

\footnotetext{
*Part of the master's thesis, "Sobrecarga em cuidadores familiares de idosos dependentes do Município de João Pessoa, Paraíba, Brasil", Graduate Program in Nursing, Federal University of Paraíba, 2011. ${ }^{1}$ Doctoral Degree from the Graduate Program in Nursing, Federal University of Paraíba. João Pessoa, PB, Brazil. laraasn@hotmail.com ${ }^{2}$ Doctorate in Sociology. Professor, Federal University of Paraíba. Leader of the Adult Health and Aging Research Group. João Pessoa, PB, Brazil. ${ }^{3}$ Nurse, Doctorate in Nursing. Professor, Department of General and Specialized Nursing, Ribeirão Preto School of Nursing, University of São Paulo. Ribeirão Preto, SP, Brazil. ${ }^{4}$ Nurse. Doctorate in Nursing. Associate Professor, Department of Public Health and Psychiatry Nursing, Graduate Program in Nursing, Federal University of Paraíba, CNPq, João Pessoa, PB, Brazil. ${ }^{5}$ Nurse. Doctorate in Nursing. Professor, Department of General and Specialized Nursing, Ribeirão Preto School of Nursing, University of São Paulo. Ribeirão Preto, SP, Brazil.
}

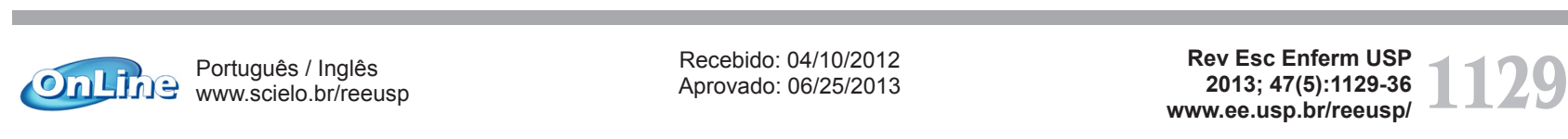




\section{INTRODUCTION}

Demographic changes as a result of the aging process occurring in contemporary society are followed by changes in morbidity and mortality of the population, which is evident in the prevalence of chronic conditions. Those affect primarily the elderly population and may eventually lead to impaired functional capacity of these individuals, who are in need of permanent care ${ }^{(1)}$.

In the presence of some event that compromises the functional capacity of the elderly, defined as capacity limitation or restriction on the performance of activities ${ }^{(2)}$, most often it is the family who takes responsibility for the care of impaired elderly, in the figure of a family caregiver or an informal caregiver. It is worth noting that the informal caregiver, beyond a family member, could be a friend, neighbor or volunteer without specific training, often unpaid, caring for the elderly side-by-side with the fami$\mid y^{(3)}$. Although he/she is often required to provide care to the impaired elder, the family caregiver does not always choose to play such a role.

Providing daily care for the elderly is a new and challenging task for the family, whose members are suddenly transformed into caregivers, often without appropriate training, knowledge or support to assume this position, which involves losses to their quality of life and also to the quality of care ${ }^{(4-5)}$. When performing activities related to the physical and psychosocial well being of the elderly, caregivers experience restrictions in relation to their own lives, which contributes to the onset of burden ${ }^{(6)}$. This phenomenon can be defined as an intrinsic dilemma of the care process, including physical, psychological, emotional, social and/or financial problems.

In Brazil, particularly in the state of Paraíba, there are few studies - especially studies with a population basis about the phenomenon of burden and its relation to characteristics inherent to impaired elderly and family caregivers. In this sense, this research is of great value, as it enables the elucidation of empirical data that can inform health professionals, above all nurses, to develop progra$\mathrm{ms}$ and policies for health interventions focused on elder care and family caregiver support.

Thus, in order to contribute to a better understanding of this topic, this study aimed to estimate the prevalence of burden in family caregivers of impaired elderly residents in João Pessoa, Paraíba, and to identify the association with social and demographic characteristics (age, sex, marital status, education, income, family structure) of the elderly dependents and their family caregivers (degree of kinship, age, gender, marital status, living with the elder, education).

\section{METHOD}

This was a cross-sectional study in the city of João Pessoa, Paraíba, part of the research entitled, Living conditions, health and aging: a comparative study, sponsored by the National Scientific Cooperation Program (PROCAD/CAPES) between the Federal University of Paraíba and the University of São Paulo Ribeirão Preto School of Nursing.

A total of 240 elders composed the study population. Those elders were residents in the city of João Pessoa, Paraíba, aged over 60 years, of both sexes, as well as family caregivers of those with an impaired functional capacity for activities of daily living. With the aim to include a sample representative of the population, and considering the socioeconomic diversity of the city, we used a probabilistic, cluster-based and double-step sampling procedure.

In the first step, we considered the census tract as the primary sampling unit. Thus, 20 census tracts were selected among the 617 sectors of the city by considering a proportional probability to the number of households. In the second step, researchers visited a fixed number of households, in order to ensure a self-weighting sample, and the streets and squares were selected to allow the onset of the sampling process.

After the selection of the sectors, researchers identified the location of each selected sector on the city map of João Pessoa, including the neighborhoods that would be visited. Then a new drawing was made to define the streets that should be visited by the interviewers. The number of the residents and the date of the home visit to conduct the questionnaire were registered on the study enrollment sheet. Finally, the responsible teams for interviewing elders and caregivers in each of the selected census tracts were determined. At the end of the pre-set interviews, in the instance in which the expected sample was not obtained, interviewers continued visits to accomplish the desired number of elders per sector. Sampling errors were fixed at $10 \%$.

We considered the following inclusion criteria: older people with moderate or severe functional disability (physical and/or cognitive), assessed by the Katz Index ${ }^{(7)}$ and the Mini-Mental State Examination (MMSE) ${ }^{(8)}$, and who had a family member as the primary caregiver. For the inclusion of caregivers we considered: men and women, who were family members of the elders, and who did not receive any payment for the delivery of care. Given these criteria, 52 elderly and their family caregivers were recruited. 
Data collection was conducted through interviews with elders and caregivers in their homes, between April to June of 2011, following the clockwise direction of the selected tracts. We used semi-structured questionnaires regarding social and demographic characteristics of the elders (age, sex, marital status, education, income, family structure) and caregivers (age, sex, relationship, marital status, education). To evaluate and rank the burden among caregivers we used the Burden Interview Scale ${ }^{(9)}$, adapted and validated in Brazil ${ }^{(10)}$, according to the following scores: intense burden (scores between 61 and 88), moderate to severe burden (scores between 41 and 60), mild to moderate burden (scores between 21 and 40), and

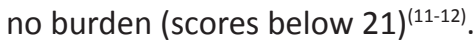

For statistical analysis, we used Statistical Package for the Social Sciences (SPSS) software for Windows, version 15.0. The description of the variables was performed by the calculation of means, standard deviations, absolute and relative frequencies. For confirmatory analysis, we used the Lilliefors test and then the normality among the variables used in the study was tested. The Student's ttest and the analysis of variance (ANOVA) were applied. We considered a significance level of $5 \%$.

As for the ethical considerations, the study was approved by the Institutional Review Board of the Lauro Wanderley University Hospital (process 679/10). Participants were informed of the study goals, the development and the disclosure of results. Moreover, we guaranteed anonymity, respect, confidentiality of information and freedom to withdraw participation in the study, in any of its phases. After the consent of subjects to participate in the study, the statement was made by signing the Terms of Free and Informed Consent form.

\section{RESULTS}

Regarding the social and demographic characteristics of the elders interviewed, we observed a prevalence of females $(55.8 \%)$, aged 80 years or more $(51.9 \%)$ or aged 75 to 79 years. Regarding marital status, $21(40.4 \%)$ were widowed, 20 (38.5\%) were married, six (11.5\%) were single and, among the others, three $(5.8 \%)$ were divorced, and two (3.8\%) were separated. Among men, the majority was married $(65.2 \%)$, while among women, there was a higher rate of widows (55.2\%).

Regarding the educational level, 22 (42.3\%) of elders reported being illiterate. Among women, 13 (44.8\%) reported illiteracy, composing the highest prevalence of this characteristic among interviewees. Among those educated, there was an average of 5.39 years of study. As for the economic situation, most were retired $(n=46$, $88.5 \%)$. As for the individual income of elders, the average was $\mathrm{R} \$ 895.35$ per month.

As for living arrangements of the elders, we identified the subsequent characteristics: mean number of people living in the same household was 4.4 , the predominant arrangement was elder/child/grandchild (19 or $36.5 \%$ ), followed by relatives such as nephews, cousins and others (20 or $38.5 \%$ ). The head of the family was the son/daughter for 22 of the study participants (42.3\%), but despite their disability, ten elderly (19.2\%) reported being the head of their families, $20(39,2 \%)$ lived in a relative's house, and 15 (29.4\%) of the family members moved into the home of the elder. The average number of children per senior was 3.71 .

Regarding the characteristics of caregivers, results on degree of kinship showed that $26(50 \%)$ of the caregivers were the son/daughter of the elder, 14 (26.9\%) were spouses, and three (5.8\%) were a son/daughter-in-law; one $(1.9 \%)$ was the grandschild and one1 $(1.9 \%)$ was a brother/sister-in-law. The remaining seven (13.5\%) had another parentage with the elder. Regarding gender, 50 (96.2\%) were women and only two (3.8\%) were men. Regarding the age of the caregivers, the mean age was 52.62 years with a standard deviation of 14.4. We observed the following caregiver ages: 12 (23.1\%) were 40 years; 12 (23.1\%) between 41 and 50 years; 11 (21.2\%) between 51 and 60 years; 11 (21.2\%) between 61 and 70 years; five (9.8\%) between 71 and 80 years; and $1(1.9 \%)$ between 81 and 90 years.

Regarding caregiver marital status, 31 (60.8\%) were married, ten (19.6\%) had never been married or lived with partners, eight (15.7\%) were divorced, and two (3.9\%) were widowed. As for educational level, 24 (46.2\%) studied five to eight years, 10 (19.2\%) for over 13 years, six (11.5\%) for one to four years and six (11.5\%) for nine to 12 years. Among those remaining, three (5.8\%) were illiterate, and three $(5.8 \%)$ reported knowing only how to informally read and write.

By applying the Burden Interview Scale ${ }^{(9)}$ we found a prevalence of burden among caregivers equivalent to $84.6 \%$, with a mean total value of 31.0 points. Considering the levels of burden, it was found that $32(61.5 \%)$ of the family caregivers had moderate to mild burden, 12 (23.1\%), moderate to severe burden, and eight (15.4\%) had no burden noted.

With regard to the items of the Burden Interview Sca$l e^{(9)}$, as shown in Table 1, caregivers showed the highest proportion of the answer never feel overwhelmed when responding to questions related to feeling embarrassed by their relative's behavior, to letting someone else take care of their relative, and feeling angry when the relative is around. Regarding the higher prevalence of caregivers who responded that they always feel overwhelmed, we observed a relationship to the fact that the elderly felt too dependent on them, as well.

Considering the relationship between caregiver burden and elder characteristics, presented in Tables 2 and 3 , there was a statistically significant association 
between those caring for the elder and type of income ( $p$-value 0.001 ), with a greater burden observed on those who had the retirement pension as the only source of income (31.15), and among caregivers who dispensed care for the elderly ( $p$-value 0.046 ). We observed a higher mean burden among caregivers who dispensed care for those elders who were also the head of their families (39.80).
In regard to the social and demographic characteristics of caregivers and the highest mean burden among them, as shown in Table 4, we found a statistically significant association between the highest mean burden and caregivers ( $p$ value 0.046 ), in that spouses had the highest burden (34.77). As for the relationship between higher levels of burden and caregiver educational level ( $p$-value 0.040), there was a higher burden among caregivers with lower educational levels.

Table 1 - Distribution of the answers to the Burden Interview Scale by family caregivers of impaired eldees - João Pessoa, PB, 2011

\begin{tabular}{|c|c|c|c|c|c|c|c|c|c|c|}
\hline & \multicolumn{2}{|c|}{ Never } & \multicolumn{2}{|c|}{ Rarely } & \multicolumn{2}{|c|}{ Sometimes } & \multicolumn{2}{|c|}{$\begin{array}{l}\text { Quite } \\
\text { frequently }\end{array}$} & \multicolumn{2}{|c|}{$\begin{array}{l}\text { Nearly } \\
\text { Always }\end{array}$} \\
\hline & $\mathbf{N}$ & $\%$ & $\mathbf{N}$ & $\%$ & $\mathbf{N}$ & $\%$ & $\mathbf{N}$ & $\%$ & $\mathbf{N}$ & $\%$ \\
\hline $\begin{array}{l}\text { 1.Do you feel that your relative asks for more help than he or } \\
\text { she needs? }\end{array}$ & 15 & $28,8 \%$ & 12 & $23,1 \%$ & 12 & $23,1 \%$ & 4 & $7,7 \%$ & 9 & $17,3 \%$ \\
\hline $\begin{array}{l}\text { 2.Do you feel that, because of the time you spend with your } \\
\text { relative, you don't have enough time for yourself? }\end{array}$ & 6 & $11,5 \%$ & 12 & $23,1 \%$ & 9 & $17,3 \%$ & 11 & $21,2 \%$ & 14 & $26,9 \%$ \\
\hline $\begin{array}{l}\text { 3. Do you feel stressed between caring for your relative and } \\
\text { trying to meet other responsibilities for your family or work? }\end{array}$ & 6 & $11,5 \%$ & 4 & $7,7 \%$ & 21 & $40,4 \%$ & 11 & $21,2 \%$ & 10 & $19,2 \%$ \\
\hline 4. Do you feel embarrassed about your relative's behavior? & 40 & $76,9 \%$ & 4 & $7,7 \%$ & 7 & $13,5 \%$ & 0 & - & 1 & $1,9 \%$ \\
\hline 5. Do you feel angry when you are around your relative? & 37 & $71,2 \%$ & 7 & $13,5 \%$ & 8 & $15,4 \%$ & 0 & - & 0 & - \\
\hline $\begin{array}{l}\text { 6. Do you feel that your relative currently affects your } \\
\text { relationship with other family members? }\end{array}$ & 35 & $67,3 \%$ & 5 & $9,6 \%$ & 9 & $17,3 \%$ & 2 & $3,8 \%$ & 1 & $1,9 \%$ \\
\hline $\begin{array}{l}\text { 7. Are you afraid about what the future holds for your } \\
\text { relative? }\end{array}$ & 7 & $13,5 \%$ & 6 & $11,5 \%$ & 22 & $42,3 \%$ & 8 & $15,4 \%$ & 9 & $17,3 \%$ \\
\hline 8. Do you feel that your relative is dependent upon you? & 0 & $0,0 \%$ & 0 & - & 6 & $11,5 \%$ & 7 & $13,5 \%$ & 39 & $75,0 \%$ \\
\hline 9. Do you feel strained when you are around your relative? & 37 & $71,2 \%$ & 5 & $9,6 \%$ & 4 & $7,7 \%$ & 4 & $7,7 \%$ & 2 & $3,8 \%$ \\
\hline $\begin{array}{l}\text { 10. Do you feel that your health has suffered because of your } \\
\text { involvement with your relative? }\end{array}$ & 20 & $38,5 \%$ & 4 & $7,7 \%$ & 14 & $26,9 \%$ & 8 & $15,4 \%$ & 6 & $11,5 \%$ \\
\hline $\begin{array}{l}\text { 11. Do you feel that you don't have as much privacy as you } \\
\text { would like, because of your relative? }\end{array}$ & 20 & $38,5 \%$ & 12 & $23,1 \%$ & 10 & $19,2 \%$ & 4 & $7,7 \%$ & 6 & $11,5 \%$ \\
\hline $\begin{array}{l}\text { 12. Do you feel that your social life has suffered because you } \\
\text { are caring for your relative? }\end{array}$ & 12 & $23,1 \%$ & 5 & $9,6 \%$ & 14 & $26,9 \%$ & 12 & $23,1 \%$ & 9 & $17,3 \%$ \\
\hline $\begin{array}{l}\text { 13. Do you feel uncomfortable having your friends over } \\
\text { because of your relative? }\end{array}$ & 32 & $61,5 \%$ & 11 & $21,2 \%$ & 9 & $17,3 \%$ & 0 & $0,0 \%$ & 0 & - \\
\hline $\begin{array}{l}\text { 14. Do you feel that your relative seems to expect you to take } \\
\text { care of him or her as if you were the only one he or she could } \\
\text { depend on? }\end{array}$ & 5 & $9,6 \%$ & 4 & $7,7 \%$ & 8 & $15,4 \%$ & 6 & $11,5 \%$ & 29 & $55,8 \%$ \\
\hline $\begin{array}{l}\text { 15. Do you feel that you don't have enough money to care } \\
\text { for your relative, in addition to the rest of your expenses? }\end{array}$ & 12 & $23,1 \%$ & 5 & $9,6 \%$ & 20 & $38,5 \%$ & 5 & $9,6 \%$ & 10 & $19,2 \%$ \\
\hline $\begin{array}{l}\text { 16. Do you feel that you will be unable to take care of your } \\
\text { relative much longer? }\end{array}$ & 27 & $51,9 \%$ & 11 & $21,2 \%$ & 10 & $19,2 \%$ & 3 & $5,8 \%$ & 1 & $1,9 \%$ \\
\hline $\begin{array}{l}\text { 17. Do you feel that you have lost control of your life since } \\
\text { your relative's death? }\end{array}$ & 34 & $65,4 \%$ & 11 & $21,2 \%$ & 4 & $7,7 \%$ & 2 & $3,8 \%$ & 1 & $1,9 \%$ \\
\hline $\begin{array}{l}\text { 18. Do you wish that you could just leave the care of your } \\
\text { relative to someone else? }\end{array}$ & 38 & $73,1 \%$ & 6 & $11,5 \%$ & 6 & $11,5 \%$ & 1 & $1,9 \%$ & 1 & $1,9 \%$ \\
\hline $\begin{array}{l}19 . \text { Do you feel uncertain about what to do about your } \\
\text { relative? }\end{array}$ & 16 & $30,8 \%$ & 11 & $21,2 \%$ & 18 & $34,6 \%$ & 7 & $13,5 \%$ & 0 & - \\
\hline $\begin{array}{l}20 \text {. Do you feel that you should be doing more for your } \\
\text { relative? }\end{array}$ & 28 & $53,8 \%$ & 10 & $19,2 \%$ & 11 & $21,2 \%$ & 2 & $3,8 \%$ & 1 & $1,9 \%$ \\
\hline $\begin{array}{l}\text { 21. Do you feel that you could do a better job in caring for } \\
\text { your relative? }\end{array}$ & 28 & $53,8 \%$ & 12 & $23,1 \%$ & 7 & $13,5 \%$ & 4 & $7,7 \%$ & 1 & $1,9 \%$ \\
\hline $\begin{array}{l}\text { 22. Overall, how burdened do you feel in caring for your } \\
\text { relative? }\end{array}$ & 9 & $17,3 \%$ & 11 & $21,2 \%$ & 15 & $28,8 \%$ & 15 & $28,8 \%$ & 2 & $3,8 \%$ \\
\hline
\end{tabular}

Burden Interview (ZARIT; ZARIT, 1987). Translated and validated to Portuguese (SCAZUFCA, 2002)

Answers to the Likert scale $(0)$ never (1) rarely (2) sometimes (3) quite frequently (4) nearly always

In item 22: (0) not at all (1) a little (2) moderately (3) quite a bit (4) extremely 
Table 2 - Distribution of mean family caregiver burden related to the social and demographic characteristics of the elders - João Pessoa, PB, 2011

\begin{tabular}{|c|c|c|}
\hline $\begin{array}{l}\text { Characteristics } \\
\text { of Elders }\end{array}$ & $\begin{array}{l}\text { Mean } \\
\text { burden } \\
\text { (SD) }\end{array}$ & p-value (*) \\
\hline \multicolumn{3}{|l|}{ Age } \\
\hline $60-64$ & $22,50(10,60)$ & \multirow{5}{*}{$0,678^{*}$} \\
\hline $65-69$ & $25,60(9,34)$ & \\
\hline $70-74$ & $39,00(16,01)$ & \\
\hline $75-79$ & $34,13(7,97)$ & \\
\hline$\geq 80$ & $28,74(9,01)$ & \\
\hline \multicolumn{3}{|l|}{ Sex } \\
\hline Male & $32,26(11,13)$ & \multirow[t]{2}{*}{$0,478 * *$} \\
\hline Female & $30,00(11,46)$ & \\
\hline \multicolumn{3}{|l|}{ Marital Status } \\
\hline Single & $26,17(5,81)$ & \multirow{5}{*}{$0,471^{*}$} \\
\hline Married & $32,65(13,10)$ & \\
\hline Divorced & $22,00(6,08)$ & \\
\hline Separated & $31,50(6,36)$ & \\
\hline Widow & $32,05(11,11)$ & \\
\hline \multicolumn{3}{|l|}{ Schooling (years of study) } \\
\hline Illiterate & $32,59(9,99)$ & \multirow{5}{*}{$0,825^{*}$} \\
\hline $0-4$ years & $33,33(13,75)$ & \\
\hline $5-8$ years & $30,92(12,39)$ & \\
\hline $9-11$ years & $26,25(15,69)$ & \\
\hline$\geq 12$ years & $27,38(10,12)$ & \\
\hline \multicolumn{3}{|l|}{ Monthly income } \\
\hline$\leq \mathrm{R} \$ 500,00$ & $39,00(28,28)$ & \multirow{5}{*}{$0,610^{*}$} \\
\hline $\mathrm{R} \$ 501,00-\mathrm{R} \$ 1.000,00$ & $31,21(11,23)$ & \\
\hline $\mathrm{R} \$ 1.001,00-\mathrm{R} \$ 1.500,00$ & $26,40(8,53)$ & \\
\hline $\mathrm{R} \$ 1.501,00-\mathrm{R} \$ 2.000,00$ & $28,33(5,50)$ & \\
\hline$\geq \mathrm{R} \$ 2.001,00$ & $33,50(14,84)$ & \\
\hline \multicolumn{3}{|l|}{ Type of income } \\
\hline Retirement & $31,15(11,57)$ & \multirow{6}{*}{$0,001^{*}$} \\
\hline Pension & $24,70(9,01)$ & \\
\hline Rent & $29,50(16,35)$ & \\
\hline Autonomous job & $26,33(17,50)$ & \\
\hline $\begin{array}{l}\text { Donations (family, friends, } \\
\text { institutions) }\end{array}$ & $23,00(8,57)$ & \\
\hline Others & $28,20(17,54)$ & \\
\hline
\end{tabular}

Table 3 - Distribution of mean family caregiver burden related to the family arrangement of elder - João Pessoa, PB, 2011

\begin{tabular}{lll}
\hline \multicolumn{1}{c}{$\begin{array}{c}\text { Characteristics } \\
\text { of Elder }\end{array}$} & $\begin{array}{c}\text { Mean } \\
\text { burden } \\
\text { (SD) }\end{array}$ & p-value (*) \\
\hline $\begin{array}{l}\text { Number of people } \\
\text { living with the elder }\end{array}$ & \\
2 people & $30,20(15,80)$ & \\
3 people & $33,31(7,99)$ & 0,232 \\
4 people & $33,33(12,86)$ & \\
5 people & $32,89(11,15)$ & \\
6 people & $14,00(1,41)$ & \\
7 people and above & $25,50(7,46)$ \\
\hline
\end{tabular}

Continuation...

\begin{tabular}{|c|c|c|}
\hline $\begin{array}{l}\text { Characteristics } \\
\text { of Elder }\end{array}$ & $\begin{array}{c}\text { Mean } \\
\text { burden } \\
\text { (SD) }\end{array}$ & p-value $(*)$ \\
\hline \multicolumn{2}{|l|}{ Who lives with the elder } & \multirow{7}{*}{0,843} \\
\hline Spouse only & $32,75(17,01)$ & \\
\hline Spouse and child & $32,43(11,48)$ & \\
\hline $\begin{array}{l}\text { Spouse, child and } \\
\text { son/daughter-in-law }\end{array}$ & $43,00(0,00)$ & \\
\hline Child only & $32,00(0,00)$ & \\
\hline $\begin{array}{l}\text { Generational arrangements } \\
\text { (elder, children and grandchildren) }\end{array}$ & $31,68(12,86)$ & \\
\hline Other & $28,85(9,06)$ & \\
\hline \multicolumn{2}{|l|}{ Head of the family } & \multirow{5}{*}{0,046} \\
\hline Elder & $39,80(11,40)$ & \\
\hline Spouse & $28,63(13,82)$ & \\
\hline Child & $29,64(9,01)$ & \\
\hline Another relative & $27,75(10,76)$ & \\
\hline \multicolumn{2}{|l|}{ Family arrangement } & \multirow{4}{*}{0,250} \\
\hline Elder lives in the relatives' house & $28,20(10,71)$ & \\
\hline Others living in the elder's house & $31,67(10,80)$ & \\
\hline Not applicable & $34,50(12,11)$ & \\
\hline \multicolumn{2}{|l|}{ Number of children } & \multirow{6}{*}{0,462} \\
\hline None & $29,25(8,79)$ & \\
\hline 1 to 2 children & $31,08(11,43)$ & \\
\hline 3 to 5 children & $34,38(12,99)$ & \\
\hline 6 to 8 children & $28,00(8,61)$ & \\
\hline$\geq 9$ children & $26,00(15,39)$ & \\
\hline
\end{tabular}

Table 4 - Distribution of mean family caregiver burden associated with the caregiver's social and demographic characteristics - João Pessoa, PB, 2011

\begin{tabular}{lll}
\hline \multicolumn{1}{c}{ Caregiver } & \multicolumn{1}{c}{$\begin{array}{c}\text { Mean } \\
\text { Purden } \\
\text { (SD) }\end{array}$} & p-value \\
\hline $\begin{array}{l}\text { Degree of Kinship } \\
\text { Spouse }\end{array}$ & $34,77(9,13)$ & \\
Child & $28,08(10,44)$ & \\
Grandchild & $28,00(0,00)$ & $0,046^{*}$ \\
Son/daughter-in-law & $34,00(15,58)$ & \\
Brother/daughter-in-law & $21,00(0,00)$ & \\
Other & $28,29(10,56)$ & \\
\hline Age & $28,91(10,74)$ & \\
$\leq 40$ years & $29,91(11,08)$ & \\
$41-50$ years & $29,63(13,85)$ & \\
$51-60$ years & $34,18(10,39)$ & \\
$61-70$ years & $33,80(12,23)$ & \\
$71-80$ years & $35,00(0,00)$ & \\
$81-90$ years & & $0,752^{* *}$ \\
\hline Sex & $28,50(10,60)$ & \\
Male & $30,13(10,51)$ & \\
Female & & \\
\hline & &
\end{tabular}


the daily delivery of care, can cause even more overload.

\begin{tabular}{ccc}
\hline $\begin{array}{c}\text { Characteristics } \\
\text { of Elder }\end{array}$ & $\begin{array}{c}\text { Mean } \\
\text { burden } \\
\text { (SD) }\end{array}$ & p-value (*) \\
\hline
\end{tabular}

\begin{tabular}{lll}
\hline Marital status & & \\
$\begin{array}{l}\text { Never married or lived } \\
\text { with a partner }\end{array}$ & $26,40(9,02)$ & $0,325^{*}$ \\
Lives with a partner & $31,57(11,12)$ & \\
Separated/ divorced & $31,00(6,71)$ & \\
Widow & $22,00(18,38)$ & $0,025^{* *}$ \\
\hline Lives with the elder & & \\
No & $17,00(7,00)$ & \\
Yes & $30,89(10,07)$ & \\
\hline Schooling & \\
Illiterate & $29,00(10,58)$ & $0,040^{*}$ \\
Can read/write & $40,00(10,81)$ & \\
informally & $28,50(10,55)$ & \\
1 - 4 years & $32,18(9,82)$ & \\
5 - 8 years & $34,33(9,48)$ & \\
9 - 12 & $21,10(7,41)$ & \\
$\geq 13$ years &
\end{tabular}

${ }^{*}$ ANOVA

** Student's t-test. $(n=52)$

\section{DISCUSSION}

The total mean burden among caregivers observed in this study was similar to other study findings $s^{(12-14)}$. Most of the research developed, both nationally and internationally, has highlighted the negative effects of being responsible for the care of an impaired elder, specifically the high incidence of burden among family caregivers. In general, they experience a greater prevalence of psychosomatic and psychiatric disorders, chronic conditions, increased consumption of psychotropic drugs, social isolation, personal or family stress, and changes in family dynamics and social life ${ }^{(15-16)}$.

Concerning the items on the Burden Interview Sca$l e^{(9)}$, the highest proportion of never feels overwhelmed answers to questions such as feeling embarrassed by the behavior of the elderly, if the caregiver would let someone else take care of the elder, and feeling angry when the elderly is around, were observed among caregivers.

It is noteworthy that the proximity and type of emotional relationship between caregivers and patients before the disease contributes to the process of integration and adaptation to this caregiver role ${ }^{(17)}$. When a close relative provides care, there may be a tendency for a better management of care, since that the previous connection of fondness, love and attention allows care to occur without being permeated by negative feelings.

Caregivers who reported that they always feel overwhelmed are evidence of a higher potential for burden. They considered that the elder depended on them to carry out many of his/her activities of daily living. The responsibility that the caregiver had for the maintenance of the elder's life, through
In the analysis of the impaired elderly characteristics related to caregiver burden, a higher mean value was observed among family caregivers taking care of elders 70 to 74 years of age, male, married, who had low income and low education level. However, one should emphasize that these results showed no significant values in the statistical analysis.

The age of the elderly seemed not to be an aspect that led to a greater burden on the caregiver; however, it is an important risk factor for the emergence of morbidities that influence the level of dependence ${ }^{(18)}$. As for the sex of the elder, men generally had more difficulty accepting the condition of dependency and the need to have someone taking care of them, contributing to the overload among family caregivers. Moreover, men worry less about maintaining their health, which makes them more susceptible to the occurrence of chronic conditions that can evolve to functional impairment.

Low income, in most cases, was related to low educational levels or, in some cases, was a consequence of the elder being force to leave his professional duties due to the worsening of the illness. Those elderly usually receive a pension lower than the wage they earned previously, causing financial losses to the caregiver and significantly overloading this person. Brazilian studies have identified the lack of financial resources as one of the main difficulties in caring for dependent relatives ${ }^{(19-20)}$. This situation affects the achievement of the necessary resources to maintain the impaired elderly, favoring the feelings of distress among caregivers, who pursue the best for their dependent relative.

Although a larger number of people living with an impaired elder can imply more possibilities for support of family caregivers and, therefore, lower the burden, this study identified a higher mean burden among caregivers who lived in multigenerational arrangements. This result may be related to the fact that a greater number of people in the house can generate more demands for the family caregiver. In addition to takinh care of the impaired elder, the caregiver is responsible for other activities related to the family. A larger number of people living together does not necessarily translate into greater support for elders and their caregivers ${ }^{(21)}$.

Regarding the relationship between caregiver burden and characteristics of the impaired elder, there was a statistically significant difference ( $p$-value of 0.046 ) between the mean value of burden and the elder living in the relatives' house. Those families headed by the impaired elder were the ones with the highest mean burden.

In the case of a condition of dependence, the elders had preserved their autonomy by maintaining respectful relationships previously built with their families, which can interfere substantially in the decision-making power 
of the caregiver. In such cases, caregivers are also dependent, not due to disability, but by other psychosocial difficulties related to the provision of care.

As for the characteristics of the caregivers, this study revealed a greater mean burden among those who were spouses of the impaired elder. Among the factors involved in such findings, we highlight caregiver limitations, since many of these caregivers were also experiencing the aging process, being vulnerable to dysfunctions resulting from senescence and illness. Additionally, throughout life, some of them may have experienced some social shortages, contributing to the deficit of social support. Moreover, there is a lack of institutional support. If caregivers receive more support, it could facilitate the home care task ${ }^{(14,18,22)}$.

Regarding the relationship between higher levels of burden and the lower educational level of the caregivers, the lack of knowledge and skills for care provision often linked to low education are responsible for feelings of anxiety and distress that impact negatively on the care delivered, as well as in caregiver's own health ${ }^{(23-24)}$. The lack of information and lack of support to deal with the care for the impaired elder expose the caregivers to a larger vulnerability to disease ${ }^{(25)}$.

\section{CONCLUSIONS}

This study results allowed final considerations, presented as the following: there was a high prevalence of

\section{REFERENCES}

1. Veras R. Envelhecimento populacional contemporâneo: demandas, desafios e inovações. Rev Saúde Pública. 2009;4(3):548-54.

2. Organização Mundial da Saúde. Classificação Internacional de Funcionalidade, Incapacidade e Saúde - CIF [Internet]. Lisboa: OMS; 2004 [citado 2012 mar. 17]. Disponível em: http://www. inr.pt/uploads/docs/cif/CIF_port_\%202004.pdf

3. Brasil. Ministério da Saúde. Portaria n. 2.528, de outubro de 2006. Aprova a Política Nacional de Saúde da Pessoa Idosa [Internet]. Brasília; 2006 [citado 2012 mar. 17]. Disponível em: http://portal.saude.gov.br/portal/arquivos/pdf/2528\%20 aprova\%20a\%20politica\%20nacional\%20de\%20saude\%20 da\%20pessoa\%20idosa.pdf

4. Inouye K, Pedrazzani ES, Pavarini SCl. Octogenários e cuidadores: perfil sócio-demográfico e correlação da variável qualidade de vida. Texto Contexto Enferm. 2008;17(2):350-7.

5. Gonçalves LHT, Costa MAM, Martins MM, Nassar SM, Zunino R. A dinâmica da família de idosos mais idosos no contexto de Porto, Portugal. Rev Latino Am Enferm. 2011;19(3):458-66. burden among caregivers (84.6\%), and some of the social and demographic characteristics of the impaired elder and the family caregivers were correlated with a higher mean burden. Among these relationships, those presenting a statistically significant association were the following: retired elder, elder as head of household, spousal caregivers, and caregivers who had less education.

It is noteworthy that although the findings of this study reflect a local reality, this research brings wider contributions since it elucidates important indicators regarding the effects of the provision of care to impaired patients and the caregiver's quality of life.

Considering the reality in which the caregivers are inserted, we identify that their visibility is reduced due to the devaluation of the work. These findings are relevant to awaken society and government regarding the pressing need to implement public policies and actions towards the establishment of formal and emotional support for these people.

Furthermore, the results of this study highlight the importance of practical interventions by nurses and other health professionals in order to improve the conditions and functional health of the elderly, as well as guidance and supervision for the care provided by family caregivers. It is remarkable that the goal of these interventions should not only equip family members as caregivers, but also as people who themselves need care.

6. Fernandes MGM, Garcia TR. Estrutura conceitual da tensão do cuidador familiar de idosos dependentes. Rev Eletr Enferm [Internet]. 2009 [citado 2012 mar. 27];11(3):469-76. Disponível em: http://www.fen.ufg.br/fen_revista/v11/n3/ pdf/v11n3a02.pdf

7. Katz, S, Ford AB, Moskowitz RW, Jackson BA, Jaffe MW. Studies of illness in the aged. The index of ADL: a standardized measure of biological and psychosocial function. JAMA. 1963;185(12):914-9.

8. Folstein MF, Folstein SE, Mchugh PR. Mini-Mental State: a practical method for grading the cognitive state of patients for the clinician. J Psychiatr Res. 1975;12(3): 189-98.

9. Zarit SH, Todd PA, Zarit JM. Subjective burden of husbands and wives as caregivers: a longitudinal study. Gerontologist. 1986;26(3):260-6.

10. Scazufca M. Versão brasileira da Escala Burden Interview para avaliação de sobrecarga em cuidadores de indivíduos com doenças mentais. Rev Bras Psiquiatr. 2002;24(1):12-7. 
11. Luzardo AR, Gorini MIPC, Silva APSS. Características de idosos com doença de Alzheimer e seus cuidadores: uma série de casos em um serviço de neurogeriatria. Texto Contexto Enferm. 2006;15(4):587-94.

12. Gratão ACM, Vendrúscolo TRP, Talmelli LFS, Figueiredo LC, Santos JLF, Rodrigues RAP. Sobrecarga e desconforto emocional em cuidadores de idosos. Texto Contexto Enferm. 2012;21(2):304-12.

13. Garrido R, Menezes PR. Impacto em cuidadores de idosos com demência atendidos em um serviço psicogeriátrico. Rev Saúde Pública. 2004;38(6):835-41.

14. Amendola F, Oliveira MAC, Alvarenga MRM. Influence of social support on the quality of life of family caregivers while caring for people with dependence. Rev Esc Enferm USP [Internet]. 2011 [cited 2012 Mar 11];45(4):884-9. Available from: http://www.scielo.br/pdf/reeusp/v45n4/en_ v45n4a13.pdf

15. Fernandes MGM, Garcia TR.Tension attributes of the family caregiver of frail older adults. Rev Esc Enferm USP [Internet]. 2009 [cited 2012 Mar 17];43(4):818-24. Disponível em: http://www.scielo.br/pdf/reeusp/v43n4/en_a12v43n4.pdf

16. Resende MC, Turra DD, Alves F, Pereira FB, Santos SAP, Trevisan VC. Cuidar de idosos com Alzheimer: influências sociais, físicas e psicológicas envolvidas nesta tarefa. RVCEH Rev Bras Cienc Env Hum. 2008;5(1):19-31.

17. Fonseca NR, Penna AFG, Soares MPG. Ser cuidador familiar: um estudo sobre as consequências de assumir este papel. Physis Rev Saúde Coletiva. 2008;18(4):727-43.

18. Fernandes MGM, Garcia TR. Determinantes da tensão do cuidador familiar de idosos dependentes. Rev Bras Enferm. 2009;62(1):57-63.
19. Martins JJ, Borges M, Silva RM, Erdmann AL, Nascimento ERP. O processo de viver e de ser cuidado de idosos e a percepção dos cuidadores. Cogitare Enferm. 2011; 16(1):96-103.

20. Moreira SR, Turrini RNT. Paciente oncológico terminal: sobrecarga del cuidador. Enferm Global [Internet]. 2011 [citado 2012 mar. 22];10(22). Disponible en: http://scielo.isciii. es/pdf/eg/v10n22/administracion2.pdf

21. Camarano AA, Kanso S, Mello JL, Pasinato MT. Famílias: espaço de compartilhamento de recursos e vulnerabilidades. In: Camarano AA, organizadora. Os novos idosos brasileiros: muito além dos 60? [Internet]. Rio de Janeiro: IPEA; 2004 [citado mar. 22]. Disponível em: http://www.ipea.gov.br/ agencia/images/stories/PDFs/livros/Arq_12_Cap_05_rachura.pdf

22. Giacomin KC, Uchôa E, Firmo JOA, Lima-Costa MF. Projeto Bambuí: um estudo de base populacional da prevalência e dos fatores associados à necessidade de cuidador entre idosos. Cad Saúde Pública. 2005;21(1):80-91.

23. Braz E, Ciosak SI. O tornar-se cuidadora na senescência. Esc Anna Nery Rev Enferm. 2009;13(2):372-7.

24. Gratão ACM, Vale FAC, Roriz-Cruz M, Haas VJ, Lange C, Talmelli LFS, et al. The demands of family caregivers of elderly individuals with dementia. Rev Esc Enferm USP [Internet]. 2010 [cited 2012 Mar 22];44(4):873-80. Available from: http://www.scielo.br/pdf/reeusp/v44n4/03.pdf

25. Del Duca GF, Martinez AD, Bastos GAN. Perfil do idoso dependente de cuidado domiciliar em comunidades de baixo nível socioeconômico de Porto Alegre, Rio Grande do Sul. Ciênc Saúde Coletiva. 2012;17(5):1159-65. 